\title{
Assessment of Trunk Control in Patients with Neuromuscular Diseases: Validity and Reliability of the Trunk Impairment Scale Nöromüsküler Hastalarda Gövde Kontrolünün Değerlendirilmesi: Gövde Bozukluk Ölçeği'nin Geçerlik ve Güvenirliği
}

\author{
(D) Yasemin Parlak Demir ${ }^{1}$, (1) Sibel Aksu Yıldırım² \\ ${ }^{1}$ Atilim University Faculty of Health Sciences, Department of Physiotherapy and Rehabilitation, Ankara, Turkey \\ ${ }^{2}$ Hacettepe University Faculty of Health Sciences, Department of Physiotherapy and Rehabilitation, Ankara, Turkey
}

\begin{abstract}
Objective: The aim of our study was to determine the reliability and validity of the Trunk Impairment Scale (TIS) in patients with adult neuromuscular diseases (NMD).

Materials and Methods: Sixty-six patients with NMD participated in the study. Patients were evaluated using the TIS, Manual Muscle Test (trunk, upper and lower extremities), Motor Function Measurement (MFM), Functional Independency Measurement (FIM), and the Rivermead Mobility Index (RMI).

Results: Test-retest reliability was excellent for the TIS. The intra-class correlation coefficient score was 0.98 . The Cronbach alpha value was 0.82 . The TIS was found to be correlated with MFM ( $r=0.30)$, MFM trunk $(r=0.31)$, trunk muscle strength $(r=0.34)$, and lower extremity muscle strength $(r=0.60$, $p<0.05)$ for construct validity. The TIS was found to be correlated with FIM $(r=0.32, p<0.05)$ and RMI $(r=0.39, p<0.05)$ for convergent validity.

Conclusion: Our results confirm that the TIS is an easy, intra-rater reliable, and a valid instrument for the measurement of trunk performance in ambulatory patients with NMD. TIS is a measure that can be completed easily and in a short time in rehabilitation clinics.
\end{abstract}

Keywords: Adult neuromuscular disease, Trunk Impairment Scale, validity, reliability

$\ddot{\mathbf{O z}}$

Amaç: Çalışmamızın amacı Gövde Bozukluk Ölçeği'nin (GBÖ) erişkin nöromüsküler hastalıklarda geçerlik ve güvenirliğini araştırmaktır.

Gereç ve Yöntem: Çalışmaya 66 nöromüsküler hastalık tanısı olan birey alındı. Çalışmaya dahil edilen olgulara GBÖ, Manuel Kas Testi (gövde, üst ve alt ekstremite), Motor Fonksiyon Değerlendirme Ölçĕ̆i (MFM), Fonksiyonel Bă̆ımsızlık Ölçeği (FIM), Rivermead Mobilite İndeksi (RMI) yapıldı.

Bulgular: GBÖ'nün test tekrar test, ICC güvenirlikleri mükemmel bulundu (GBÖ: 0,96 ve 0,98). Cronbach alfa katsayısı 0,82 bulundu. Yapı geçerliği için GBÖ ile MFM ( $r=0,29)$, MFM gövde ( $r=0,31)$, toplam gövde kas kuvveti $(r=0,34)$, toplam alt ekstremite kas kuvveti $(r=0,34$, p<0,05), toplam kas kuvveti $($ gövde, alt ve üst ekstremite) $(r=0,52, p<0,05)$ arasında anlamlı ilişki bulundu. GBÖ uyum geçerliği için FIM $(r=0,32, p<0,05)$ ve RMI $(r=0,39$, p<0,05) ile ilişkili bulundu. Sonuç: Çalışmanın sonucunda GBÖ'nün erişkin kas hastalıklarında yapı ve uyum geçerliliğinin olduğu ve mükemmel güvenirliğe sahip olduğu bulundu. GBÖ rehabilitasyon kliniklerinde uygulaması kolay ve kısa zaman alan bir ölçektir.

Anahtar Kelimeler: Erişkin nöromüsküler hastalık, Gövde Bozukluk Ölçeği, geçerlik, güvenirlik

\section{Introduction}

Trunk control plays a key role in activities of daily living. Good trunk stabilization is a fundamental part of postural control in the organization of postural and righting reactions, the facilitation of distal movement, and provision of the connection between the shoulder and pelvis, and appropriate gait pattern $(1,2,3,4,5)$.

The majority of neuromuscular diseases (NMD) are progressive and have a tendency to involve trunk and proximal extremity muscles. As a result, difficulties in extremity function and mobility

Address for Correspondence/Yazışma Adresi: Yasemin Parlak Demir MD, Atilim University Faculty of Health Sciences, Department of Physiotherapy and Rehabilitation, Ankara, Turkey

Phone: +90 3125868469 E-mail: fztyasemin@yahoo.com ORCID ID: orcid.org/0000-0001-5064-1197

Received/Geliş Tarihi: 31.07.2017 Accepted/Kabul Tarihi: 20.10.2017

Published in: The research was presented at the $1^{\text {th }}$ International Congress of the World Muscle Society, October 2013 , Asilomer, USA. 
and compensatory responses of the trunk can be observed in these patients $(2,5,6,7,8,9,10,11,12)$.

It is critical to assess trunk control in NMD using a standard, objective clinical test in order to define its contribution to accompanying dysfunctions and secondary complications. A comprehensive assessment of trunk functions in NMD may help to determine the primary problems related to the trunk, explain the role of trunk control in the current functional level, and structureappropriate interventions including trunk exercises.

The Trunk Impairment Scale (TIS) was developed by Verheyden et al. (13) in 2004. Trunk performance and coordination can be tested during static and dynamic sitting balance with the TIS. Its validity and reliability has been established in various neurologic diseases such as stroke, multiple sclerosis (MS), traumatic brain injury (TBI), and Parkinson's disease $(13,14,15,16)$.

The aim of the present study was to explore psychometric properties such as construct validity, convergent validity, testretest reliability and internal consistency reliability of the TIS, which is used to evaluate trunk control in NMD.

\section{Materials and Methods}

Patient recruitment: The study was carried out in 2011 at the Hacettepe University Faculty of Health Sciences, Department of Physiotherapy and Rehabilitation, Unit of Neurological Rehabilitation, Ankara, Turkey. Seventy-five patients who were diagnosed as having NMD by the neurology department of Hacettepe University were invited to participate in the study. The inclusion criteria were age over 18 years, free of orthopedic problems affecting trunk and extremity performance, free of serious neurologic disorders other than NMD and cognitive disorders or difficulty with cooperation, and the ability to walk outside (with or without the assistance of a device).

Subjects were excluded from the study if they did not come to the second evaluation, they were bed bound, or had spinal or orthopedic surgery. All patients visiting our clinic reporting NMDs were requested to participate in the study if they fulfilled the inclusion criteria. The data collection and evaluation procedure is shown in Figure 1.

Ethical approval was obtained from the Hacettepe University Medical, Surgical and Drug Research Ethics Committee (approval number: LUT 11/07-03, date: 03.02.2011) and the study was conducted in accordance with the principles of the Helsinki declaration. Informed consent was obtained from all patients.

\section{Reliability Measurements}

Cronbach alpha coefficient $(\alpha)$ was calculated for internal consistency.

Test-retest Reliability: TIS was administered twice. The period between measurements was 7 days. Test-retest reliability was determined by using the intra-class correlation coefficient (ICC) and Bland-Altman plot.

Convergent Validity: For this purpose, the relation between TIS (0-23) and Functional Independence Measure (FIM) (the score of FIM is between 18-126) (17) and the Rivermead Mobility Index (RMI) (18) were examined.

Construct Validity: The construct validity was examined by comparing the TIS with the Motor Function Measurement (MFM) (the score of MFM is between 0-96), with MFM trunk subsection $($ MFM trunk = sum of D1 sub-item scores of MFM and D2 sub-item scores of MFM) (19), Manual Muscle Test

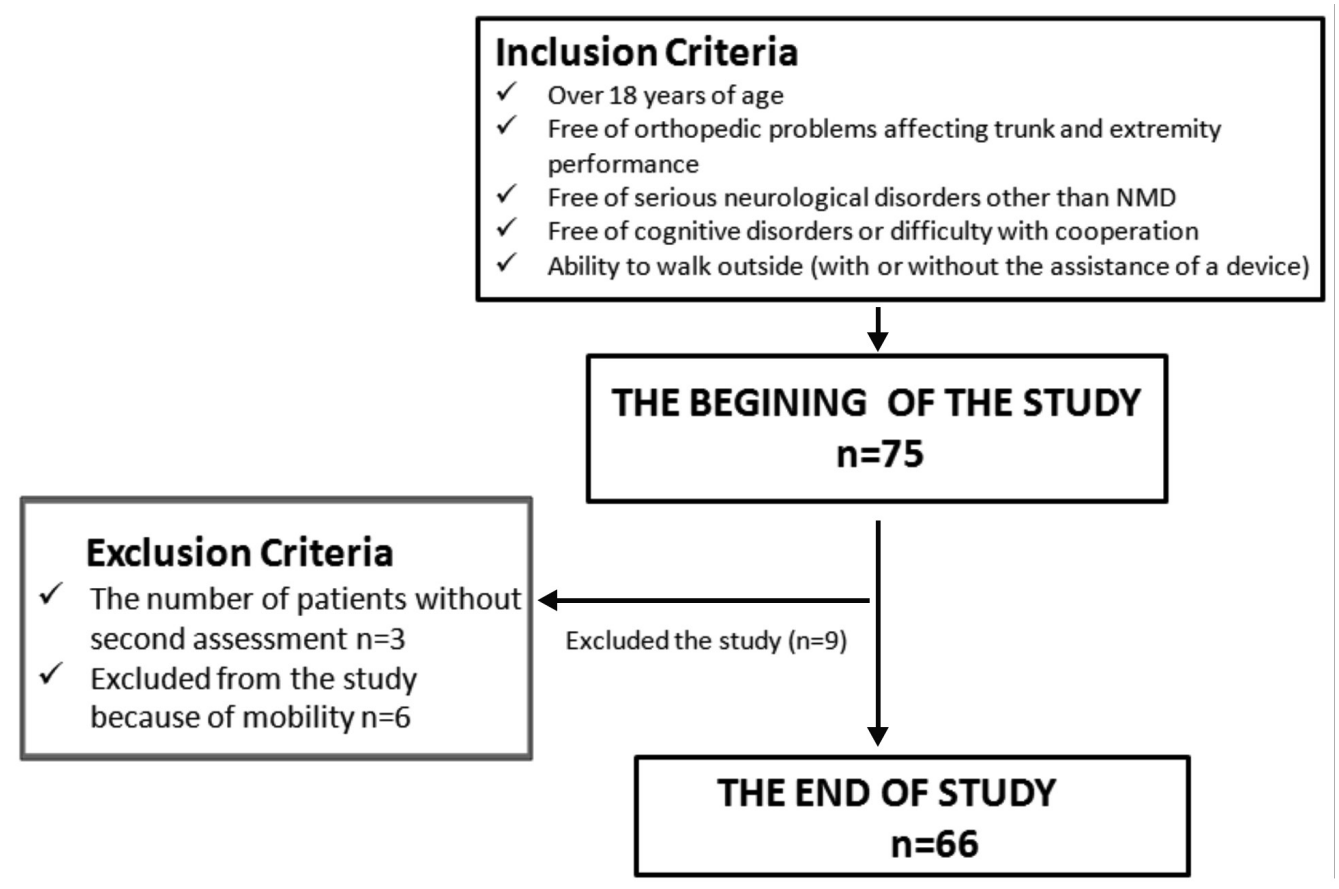

Figure 1. The flow chart of data collection and evaluation procedure

NMD: Neuromuscular diseases 
(MMT) (the score of MMT between 0-5) (20) using Spearman's correlation.

\section{Assessment Procedure}

At the beginning of the study, demographic characteristics and other related history were recorded for each patient. The MMT, MFM, MFM trunk, the self-report version of the FIM, and the RMI were considered as comparator instruments in this study. For the test-retest reliability, the same rater repeated all the assessments a week later. During this period, no medical treatment was given. After the initial assessment, all patients were given a standard home exercise program. The subjects did not continue with their routine during the intervening period of 7 days. Assessments were performed by a physiotherapist who has over 10 years' professional experience.

\section{Assessment Tools}

Trunk performance was assessed using the TIS. This scale comprises 17 items and evaluates static and dynamic sitting balance and trunk co-ordination. The items of the TIS are scored on a 2-, 3- or 4-point ordinal scale. The total score ranges from a minimum of 0 to a maximum 23 points, higher scores indicate better performance. The time to apply the TIS to the patients is between 6 and 16 minutes (13).

The muscle strength of the patients was measured using the MMT (0-5) (20). The upper and lower abdominal muscles, back extensors, internal and external obliques, and lateral flexor muscles of the trunk were examined. For the extremities, the muscle strength of shoulder flexors, extensors and abductors, as well as hip flexors, extensors and abductors were examined. These results were gathered on the right and left side separately and added together to find the total lower and upper extremity muscle strength. Total muscle strength (0-105) was also obtained by the summation of trunk (0-35), upper (0-30), and lower extremity muscle strength (0-40) $(21,22,23,24,25)$

The motor functional level was evaluated using the MFM, which is a reliable and valid measurement in people with NMD. The total score ranges from 0 to 96 when summing the 32 items (19). MFM trunk includes D1 and D2 subsections. D1 contains 13 items, which are tested in the standing position and using transfers. D2 consists of 12 items representing axial and proximal limb motor function (19).

The self-report version of the FIM was used for the assessment of daily life activity level (17). Possible scores range from 18 to 126, with higher scores indicating more independence.

The mobility level of the patients was evaluated using the RMI (0-15) (18). Higher scores indicate a better mobility level. The RMI was shown to be a reliable and valid measurement in patients with neurologic diseases $(26,27)$.

\section{Statistical Analysis}

The statistical analysis was performed using the SPSS system (version 16.0, SPSS Inc., Chicago, IL, USA). Values are expressed as mean \pm standard deviation (SD) or as percentages. The Kolmogorov-Smirnov test was used to investigate the normality of the distribution of quasi dimensional variables. Descriptive statistics are given as mean $\pm \mathrm{SD}$ or median (minimum-maximum) for quasi dimensional variables and as the number of patients and percentage $(\%)$ for categorical variables.
The differences between the two measures were evaluated using the paired-sample t-test because the distribution of the data for test-retest reliability was as normal, and differences between two pairs were evaluated using the significance test and Spearman's rank correlation coefficient (28). For the test-retest reliability, intra-rater test-retest reliability for 'absolute agreement' was determined using the ICC (ICC 2,1; two-way random, single measure) and Bland-Altman plot. ICCs can vary from 0.00 to 1.00 where values of 0.60 to 0.80 are regarded as evidence of good reliability, with those above 0.80 indicating excellent reliability. For internal consistency with Cronbach alpha and item-total correlation: Cronbach's alpha assesses the overall correlation between items within a scale, and values greater than or equal to 0.7 are considered acceptable. Item-total correlation measures the strength of association between an item and the remainder of its scale, and correlations of 0.4 or above are considered acceptable (29). A correlation coefficient (r) greater than 0.60 was regarded as a strong correlation, $\mathrm{r}=0.30-0.60$ was regarded as a moderate correlation, and $r<0.30$ was regarded as a weak correlation. The relationship was evaluated using Spearman's correlation analysis (30). The probability of error was considered as $\mathrm{p}<0.05$ (31).

\section{Results}

The sample analysis included a total of 66 adults, $41(62 \%)$ of whom were males and $25(38 \%)$ were females. The percentage of subjects retained was $91 \%$. The mean patient age was $35.0 \pm 11.5$ years. Out of 66 patients, $31(46.9 \%)$ had myopathy, $22(33.3 \%)$ had myotonic dystrophy, $7(10.7 \%)$ had limb girdle muscular dystrophy, 3 (4.5\%) had fascio-scapulohumeral muscular dystrophy (FSHMD), and $3(4.5 \%)$ had Becker muscular dystrophy. The duration of disease was $10.7 \pm 7.7$ years.

\section{Reliability and Validity}

The TIS had good reliability with an ICC score $(\mathrm{ICC}=0.98)$ for test-retest reliability. There was no difference between the testretest scores $(p=0.08)$. The results of the reliability analysis are shown in Table 1.

The Bland-Altman plot of test-retest assessment of the TIS are shown in Figure 2.

Cronbach's alpha coefficient was 0.82 (excellent). Item- total correlation coefficient for "static sitting balance", "dynamic sitting balance" and "coordination" were $(r=0.76, p<0.001),(r=0.86$, $\mathrm{p}<0.001)$, and $(\mathrm{r}=0.76, \mathrm{p}<0.001)$, respectively. TIS was found to have a strong correlation with all items. The TIS was found to be moderately correlated with MFM ( $r=0.30)$, MFM trunk $(r=0.39)$, MFM D1 subsection ( $r=0.34)$, MFM D2 subsection (0.37), FIM $(r=0.32)$, RMI ( $r=0.39)$, trunk muscle strength $(r=0.34)$, lower extremity MMT ( $\mathrm{r}=0.60)$, total of muscle strength (trunk, upper and lower muscle strength) $(\mathrm{r}=0.53)$ for convergent validity. These

\begin{tabular}{|llllllll}
\hline \multicolumn{3}{c}{ Table } & 1. Test-retest reliability of Trunk Impairment Scale \\
Test & Re-test & & \multicolumn{4}{c}{ Reliability } \\
n=66 & $\mathbf{M} \pm$ SD & $\mathbf{M}_{ \pm}$SD & p & t & ICC & 95\% CI \\
TIS & $18.48 \pm 4.19$ & $18.71 \pm 4.07$ & 0.080 & -1.759 & 0.979 & $0.965-0.987$ \\
\hline
\end{tabular}

Paired Samples test, $\mathrm{p}<0.05, \mathrm{M}$ : Mean, SD: Standard deviation, ICC: Intercorrelation coefficient, CI: Confidence interval, TIS: Trunk Impairment Scale, p: Correlation coefficient,
Probability of error 
results showed construct and convergent validity of the TIS in patients with NMD. Validity values are presented in Table 2 and Table 3.

\section{Discussion}

The most important result of our study, in which we draw attention to the assessment of trunk control in NMD, is the fact that the TIS is an intra-rater reliable and valid test that can yield results related to a patient's functional level and guide physicians during the clinical treatment period.

Verheyden et al. (13) performed the construct and concurrent validity of the TIS by comparing it with the Barthel Index $(r=0.86)$ and Trunk Control Test $(r=0.83)$ respectively, on patients with stroke. As a result, the TIS was found to be highly related in them. In reliability analysis, the Cronbach alpha value of the TIS was found as 0.89 (13). Our result related to the construct validity of TIS was not as high as Verheyden et al.'s (13) study, although the Cronbach alpha was higher in our study.

In our study, TIS moderately correlated with MFM $(r=0.30)$ and MFM trunk $(r=0.39)$ for construct validity. We were led to believe that heterogeneity in muscle involvement among our patients was the most significant factor in this result. Therefore, we believe that it is possible to obtain different results in a more homogeneous group of ambulatory patients with NMD.

In the present study, we found that TIS correlated strongly with the total muscle strength of the lower limb-one of the comparator instruments-and moderately with trunk muscle strength. The TIS includes some sub-items such as leg crossing, lifting the pelvis from the bed or table, rotating the upper trunk, and rotating the lower trunk. Accordingly, we do not expect high correlation only trunk muscle strength. Generally, the compensation of the movement of the trunk is maintained with the movement of the lower extremities in NMD (32). On the

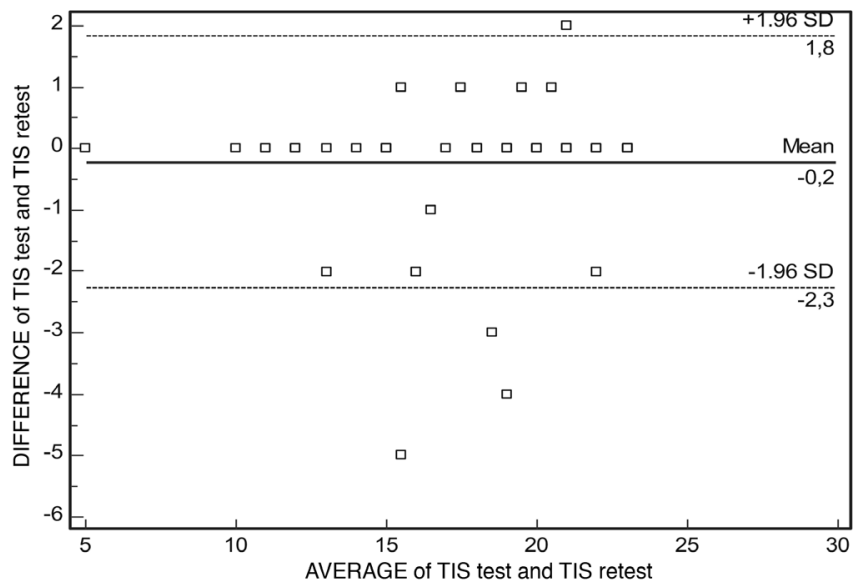

Figure 2. Bland Altman plot* for test- retest reliability SD: Standard deviation, TIS test: First assessment of Trunk Impairment Scale, TIS retest: Second assessment of Trunk Impairment Scale, $X$ axis: Average of TIS test and TIS retest, $Y$ axis: Differences of TIS test and TIS retest.

*Very few points are visible in the Bland-Altman plot because the TIS scores were not continuous data, so there was no decimal number other hand, it correlated strongly with the total of upper and lower limb, and trunk muscle strengths. This result indicates that the TIS can reflect the relationship between trunk control and progressive muscle weakness, which is the primary problem in NMD. The TIS can be used to rapidly gather information on disorders of trunk control and changes in or maintaining muscle strength when examination of isolated muscle strengths is not an option due to time management and practical reasons, as in out-patient clinics.

Verheyden et al. (15) examined the inter-rater reliability and found that the reliability of items 3 and 10 of the dynamic sitting balance subscale, which assess compensation strategies, were low in patients with MS. A similar result was also reported in patients with stroke (13). In the present study, assessments were made by the same rater, and therefore our study is limited for inter-rater

Table 2. Correlations of the Trunk Impairment Scale with other measures of physical status for validity

\begin{tabular}{|c|c|c|c|c|}
\hline $\begin{array}{l}\text { Other } \\
\text { measures }\end{array}$ & $\mathrm{M} \pm \mathrm{SD}$ & $\mathbf{r}$ & $95 \% \mathrm{CI}$ & $\mathrm{p}$ \\
\hline MFM (0-96) & $76.74 \pm 13.25$ & $0.300^{*}$ & $0.063-0.505$ & $0.015^{*}$ \\
\hline $\begin{array}{l}\text { MFM trunk } \\
(\mathrm{D} 1+\mathrm{D} 2 \\
\text { subsections) } \\
(0-75)\end{array}$ & $57.28 \pm 11,44$ & $0.388^{*}$ & $0.162-0.575$ & $0.001^{*}$ \\
\hline $\begin{array}{l}\text { MFM D1 } \\
\text { subsection } \\
\text { (standing } \\
\text { position and } \\
\text { using transfers) } \\
(0-36)\end{array}$ & $23.36 \pm 9.48$ & $0.344^{*}$ & $0.112-0.540$ & $0.005^{*}$ \\
\hline $\begin{array}{l}\text { MFM D2 } \\
\text { subsection } \\
\text { (axial and } \\
\text { proximal limb } \\
\text { motor function) } \\
(0-39)\end{array}$ & $33.92 \pm 3.10$ & $0.379^{*}$ & $0.151-0.568$ & $0.002^{*}$ \\
\hline $\begin{array}{l}\text { Trunk manual } \\
\text { muscle test } \\
(0-35)\end{array}$ & $21.05 \pm 4.75$ & $0.344^{*}$ & $0.112-0.540$ & $0.005^{*}$ \\
\hline $\begin{array}{l}\text { Lower extremity } \\
\text { manual muscle } \\
\text { test }(0-40)\end{array}$ & $28.16 \pm 5.98$ & $0.600^{*}$ & $0.419-0.735$ & $<0.001^{*}$ \\
\hline $\begin{array}{l}\text { Upper } \\
\text { extremity } \\
\text { manual muscle } \\
\text { test }(0-30)\end{array}$ & $24.94 \pm 4.13$ & 0.269 & $0.029-0.479$ & 0.065 \\
\hline $\begin{array}{l}\text { Total of muscle } \\
\text { strength }(0-105)\end{array}$ & $75.35 \pm 11.19$ & $0.527^{*}$ & $0.327-0682$ & $<0.001^{*}$ \\
\hline FIM (18-126) & $121.34 \pm 8.58$ & $0.323^{*}$ & $0.088-0.524$ & $0.008^{*}$ \\
\hline RMI (0-15) & $12.96 \pm 2.82$ & $0.391^{*}$ & $0.165-0.578$ & $0.002^{*}$ \\
\hline \multicolumn{5}{|c|}{$\begin{array}{l}\text { Spearman correlation, }{ }^{*} \mathrm{p}<0.05 \text {, SD: Standard deviation, M: Mean, r: Correlation } \\
\text { coefficient, p: Probability of error, MFM trunk: Sum of D1 and D2 subsections } \\
\text { score of Motor Function Measurement that assess trunk control, CI: Confidence } \\
\text { interval, MFM: Motor Function Measurement, FIM: Functional Independency } \\
\text { Measurement, RMI: Rivermead Mobility Index }\end{array}$} \\
\hline
\end{tabular}


reliability.

Our research is the only study of the test-retest reliability of the TIS using the Bland-Altman plot in the literature. Less than 66 points are visible on the Bland-Altman plot, so much overlap would be unexpected, but the TIS score was not continuous data, so there was no decimal numbers. It may cause overlap.

Verheyden et al.'s (16) validity study of TIS in patients with Parkinson's disease compared the TIS with the Unified Parkinson's Disease Rating Scale. The authors found a correlation with the subgroup showing motor disorder and demonstrated its validity. This result is in agreement with ours. Furthermore, performance in shoulder and pelvis rotation is assessed with the coordination subscale of the TIS. It has been shown that this is important in defining the freezing pattern due to rigidity in Parkinson's disease. In contrast, the performances of the upper and lower segments of the body are not parallel as a result of progressive weakness of muscles around the shoulder girdle and pelvis, depending on the type of NMD. Therefore, although the performance of the shoulder girdle in time is important in FSHMD, the performance of the pelvic girdle is important in Duchenne muscular dystrophy. The TIS can reflect the relationship between different muscles affected by the disease and trunk control.

A moderate correlation was found between TIS and FIM with respect to convergent validity $(r=0.32)$. Contrary to other studies, this rate is lower than expected in our study. The FIM was developed to measure physical and cognitive disability in all ages and diagnosis. However, due to cognitive functions generally being intact in patients with NMD, the total score may be higher than expected. Therefore, it suggests that either functional changes measured through FIM do not translate into trunk control or there is a deficiency in measuring the trunk control as a result of the nature of functional scale.

In the literature, special consideration for measurement and evaluation criteria is necessary, especially in disability outcome research, in which generic instruments remain weak. In the study by Andresen (30), for patient-centered and clinical research with multi-triad and multi-method matrix features, the correlation coefficient was regarded as strong if $r>60$, moderate if $r<60$, and weak if $\mathrm{r}<30$. Therefore, even a 0.32 correlation coefficient may clinically significant for progressive NMD.

Mobility is the activity with which patients with NMD have the most difficulty. Lower limb muscle strength is the most effective factor for the individual to maintain independent ambulation (33). A moderate relation $(r=0.39)$ exists between TIS and RMI, which measures the level of mobility. However, we believe that the level of relation with RMI might be affected as the disease progressed because deficiency in trunk control in our patients was minimal.

Previous results of test-retest reliability, expressed as ICC, of the TIS in patients with stroke, MS, Parkinson's disease, and TBI was similar to our results $(13,14,15,16,34)$. The high reliability of the scale, when administered by the same rater, is an important

\begin{tabular}{|c|c|c|c|c|c|}
\hline Muscle strengths $(0-5)$ & Right/Left & $\mathrm{M} \pm \mathrm{SD}$ & $\mathbf{r}$ & $\mathrm{p}$ & $95 \% \mathrm{CI}$ \\
\hline Hip flexion & $\begin{array}{l}\text { Right } \\
\text { Left }\end{array}$ & $\begin{array}{l}3.87 \pm 0.84 \\
3.87 \pm 0.88\end{array}$ & $\begin{array}{l}0.541^{*} \\
0.596^{*}\end{array}$ & $\begin{array}{l}<0.001 \\
<0.001\end{array}$ & $\begin{array}{l}0.345-0.692 \\
0.414-0.732\end{array}$ \\
\hline Hip extension & $\begin{array}{l}\text { Right } \\
\text { Left }\end{array}$ & $\begin{array}{l}3.32 \pm 1.14 \\
3.29 \pm 1.18\end{array}$ & $\begin{array}{l}0.342 \\
0.364\end{array}$ & $\begin{array}{l}0.017 \\
0.011\end{array}$ & $\begin{array}{l}0.109-0.539 \\
0.134-0.556\end{array}$ \\
\hline Hip abduction & $\begin{array}{l}\text { Right } \\
\text { Left }\end{array}$ & $\begin{array}{l}4.20 \pm 0.98 \\
4.28 \pm 0.94\end{array}$ & $\begin{array}{l}0.213 \\
0.271\end{array}$ & $\begin{array}{l}0.146 \\
0.040\end{array}$ & $\begin{array}{l}-0.030-0.432 \\
0.032-0.481\end{array}$ \\
\hline Hip adduction & $\begin{array}{l}\text { Right } \\
\text { Left }\end{array}$ & $\begin{array}{l}3.07 \pm 1.06 \\
3.14 \pm 1.20\end{array}$ & $\begin{array}{l}0.500^{*} \\
0.637^{*}\end{array}$ & $\begin{array}{l}<0.001 \\
<0.001\end{array}$ & $\begin{array}{l}0.294-0.661 \\
0.467-0.761\end{array}$ \\
\hline Shoulder flexion & $\begin{array}{l}\text { Right } \\
\text { Left }\end{array}$ & $\begin{array}{l}4.26 \pm 0.86 \\
4.31 \pm 0.80\end{array}$ & $\begin{array}{l}0.201 \\
0.132\end{array}$ & $\begin{array}{l}0.171 \\
0.370\end{array}$ & $\begin{array}{l}-0.043-0.422 \\
-0.113-0.362\end{array}$ \\
\hline Shoulder extension & $\begin{array}{l}\text { Right } \\
\text { Left }\end{array}$ & $\begin{array}{l}3.82 \pm 1.14 \\
3.83 \pm 1.11\end{array}$ & $\begin{array}{l}0.271 \\
0.234\end{array}$ & $\begin{array}{l}0.062 \\
0.109\end{array}$ & $\begin{array}{l}0.032-0.480 \\
-0.008-0.450\end{array}$ \\
\hline Shoulder abduction & $\begin{array}{l}\text { Right } \\
\text { Left }\end{array}$ & $\begin{array}{l}4.36 \pm 0.78 \\
4.35 \pm 0.78\end{array}$ & $\begin{array}{l}0.291 \\
0.219\end{array}$ & $\begin{array}{l}0.045 \\
0.134\end{array}$ & $\begin{array}{l}0.053-0.497 \\
-0.024-0.437\end{array}$ \\
\hline Trunk oblique flexion & $\begin{array}{l}\text { Right } \\
\text { Left }\end{array}$ & $\begin{array}{l}3.21 \pm 1.03 \\
3.21 \pm 1.03\end{array}$ & $\begin{array}{l}0.222 \\
0.222\end{array}$ & $\begin{array}{l}0.073 \\
0.222\end{array}$ & $\begin{array}{l}-0.021-0.440 \\
-0.021-0.440\end{array}$ \\
\hline Trunk lateral flexion & $\begin{array}{l}\text { Right } \\
\text { Left }\end{array}$ & $\begin{array}{l}2.12 \pm 0.43 \\
2.14 \pm 0.45\end{array}$ & $\begin{array}{l}0.025 \\
0.043\end{array}$ & $\begin{array}{l}0.845 \\
0.735\end{array}$ & $\begin{array}{l}-0.218-0.265 \\
-0.201-0.282\end{array}$ \\
\hline Upper trunk flexion & Bilateral & $3.29 \pm 1.14$ & $0.412 *$ & 0.001 & $0.189-0.594$ \\
\hline Lower trunk flexion & Bilateral & $4.04 \pm 1.30$ & $0.262^{*}$ & 0.034 & $0.022-0.549$ \\
\hline Trunk extension & Bilateral & $2.96 \pm 0.93$ & $0.355^{*}$ & 0.003 & $0.124-0.549$ \\
\hline
\end{tabular}


psychometric feature of the scale, especially in patients with progressive NMD.

The TIS was developed to observe trunk movements used during daily life activities and the quality of trunk performance, and to measure trunk coordination. Trunk performance while sitting was evaluated with the TIS. Therefore, it can be used in early stages of NMD and in patients who have not lost the capacity for ambulation.

One of the limitations of this study was the inclusion of a heterogeneous NMD patient group. Hence, designing future studies with patients with the same NMD is recommended to make sure that muscle strength would be affected relatively uniformly. Interrater reliability is important for wide range of using of TIS and it may enable to evaluate the same patient by different physicians. Moreover, in future studies, other psychometric characteristics of NMD such as responsiveness, sensitivity, and inter-rater reliability should also be investigated.

\section{Conclusion}

Our results confirm that the TIS is an easy, reliable and valid instrument for the measurement of trunk performance in ambulatory patients with NMD. The TIS leads physicians during the decision-making stage by yielding information regarding trunk functional status. It can be tentatively suggested that the TIS is more suitable in the early stages of NMD. Further studies should investigate whether the TIS allows comparison of trunk function in patients with different mobility levels.

\section{Clinical Messages for Best Practice:}

- TIS, administered by the same rater, is a valid and reliable method to assess trunk control in patients with NMD.

- TIS can be used in the early stages of NMD and in patients who did not lose ambulation capacity.

Ethics

Ethics Committee Approval: The study was approved by the Ethical approval was obtained from the Hacettepe University Medical, Surgical and Drug Research Ethics Committee (approval number: LUT 11/07-03, date: 03.02.2011) and was conducted in accordance with the principles of the Helsinki Declaration.

Informed Consent: Informed consent was obtained from all patients.

Peer-review: Externally and internally peer-reviewed.

\section{Authorship Contributions}

Concept: Y.P.D., Design: Y.P.D, S.A.Y., Analysis or Interpretation: Y.P.D., S.A.Y., Data Collection or Processing Y.P.D., Literature Search: Y.P.D., W riting: Y.P.D.

Conflict of Interest: The authors were declared no conflicts of interest.

Financial Disclosure: The authors declared that this study received no financial support.

\section{References}

1. Hodges PW, Richardson CA. Contraction of the Abdominal Muscles Associated with Movement of the Lower Limb. Phys Ther 1997;77:132-187.

2. Nätterlund B, Ahlström G. Activities of daily living and quality of life in person with muscular dystrophy. J Rehabil Med 2001;33:206-211.
3. Mc Donald CM. Physical activity, health impairments and disability in neuromuscular disease, Am J Phys Med Rehabil (Suppl) 2002;108-120.

4. Tiffreau V, Viet G, Thevenon A. Pain and Neuromuscular Disease: The Result of a Survey, Am J Phys Med Rehabil 2006;85:756-766.

5. Wiles CM, Buse ME, Sampson CM, Rogers MT, Fenton-May J, Van Deursen R. Falls and Stumbles in Myotonic Dystrophy. J Neurol Neurosurg Psychiatry 2006;77:393-396

6. Nätterlund B, Ahlström G. Activities of Daily Living and Quality of Life in Person with Muscular Dystrophy. J Rehabil Med 2001;33:206-211.

7. Bohannon RW. Recovery and Correlates of Trunk Muscle Strength After Stroke. Int J Rehabil Res 1995;18:162-167.

8. Lord J, Behrman B, Varzos N, Cooper D, Lieberman JS, Fowler WM Scoliosis Associated with Duchenne Muscular Dystrophy. Arc Phys Med Reh 1990;71:13-17.

9. Mcdonald CM. Physical Activity, Health Impairments and Disability in Neuromuscular Disease. Am J Phys Med Rehabil 2002;(Suppl):108-120.

10. Parlak Demir Y, Aksu Yıldırım S. Reliability and Validity of Trunk Control Test in patients with neuromuscular diseases. Physiother Theo and Prac 2015;31:39-44.

11. Tiffreau V, Viet G, Thevenon A. Pain and Neuromuscular Disease: The Result of a Survey. Am J Phys Med Rehabil 2006;85:756-766.

12. Vandervelde L, Van Den Bergh P, Goemans N, Thonnard J. Actıvelım: A Rasch-Built Measure of Activity Limitations in Children and Adults with Neuromuscular Disorders. Neuromuscul Disord 2007;17:459-469.

13. Verheyden G, Nieuwboer A, Mertin J, Preger R, Kiekens C, De Weerdt W. The Trunk Impairment Scale: A New Tool to Measure Motor Impairment of the Trunk After Stroke. Clin Rehabil 2004;18:326-334.

14. Verheyden G, Nuyens G, Nieuwboer A, Van Asch P, Ketelaer P, De Weerdt W. Reliability and Validity of Trunk Assessment for People With Multiple Sclerosis. Phys Ther 2006;86:66-76.

15. Verheyden G, Hughes J, Jelsma J, Nieuwboer A, De Weerdt W. Assessing Motor Impairment of The Trunk in Patients With Traumatic Brain Injury: Reliability and Validity of the Trunk Impairment Scale. S Afr J Physiother 2006;62:23-28.

16. Verheyden G, Willems AM, Ooms L, Nieuwboer A. Validity of the Trunk Impairment Scale as a Measure of Trunk Performance in People With Parkinson's Disease. Arch Phys Med Rehabil 2007;88:1304-1308.

17. Jensen MP, Abresch RT, Carter GT. The reliability and validity of a selfreport version of the FIM instrument in persons with neuromuscular disease and chronic pain. Arch Phys Med Rehabil 2010;86:116.

18. Collen FM, Wade DT, Robb GF and Bradshaw CM. The Rivermead Mobility Index: A further development of the rivermead motor assessment. Int Disabil Stud 1991;13:50-54.

19. Be'rard C, Payan C, Hodgkinson I, Fermanian J. A motor function measure scale for neuromuscular diseases. Construction and validation study. Neuromuscul Disord 2005;15:463-470.

20. Mendell J.R, Florance J. Manual muscle testing. Muscle Nerve Suppl 1990;16-20.

21. Brooke MH, Griggs RC, Mendell JR, Fenichel GM, Shumate JB, Pellegrino RJ. Clinical trials in Duchenne dystrophy. I. The design of the protocol. Muscle Nerve 1981;4:186-197.

22. Cuthbert SC, Goodheart GJ. On the reliability and validity of manual muscle testing: a literature review. Chiroprac Osteo 2007;15:4.

23. İyigün G, Aksu Yıldııım S, Atay S, Kılınç M, Tan E. Factors negatively affecting falling in patients with neuromuscular diseases: a prospective study. Fizyoter Rehabil 2008;19:97-103.

24. Scott OM, Hyde SA, Goddard C, Dubowitz V. Quantitation of muscle function in children: a prospective study in Duchenne muscular dystrophy. Muscle Nerve 1982;5:291-301.

25. Rider LG, Koziol D, Giannini EH, Jain MS, Smith MR, Whitney-Mahoney K, Feldman BM, Wright SJ, Lindsley CB, Pachman LM, Villalba ML, Lovell DJ, Bowyer SL, Plotz PH, Miller FW, Hicks JE. Validation of manual muscle testing and a subset of eight muscles for adult and juvenile idiopathic inflammatory myopathies. Arthritis Care Res 2010;62:465-472.

26. Rossier P and Wade DT. Validity and reliability comparison of 4 mobility measures in patients presenting with neurologic impairment. Arch Phys Med Rehabil 2001;82:9-13. 
27. Akın B, Emiroğlu ON. The validity and reliability of the Turkish version of Rivermead Mobility Index in the elderly. Turk J Geriatr 2007;10:124130.

28. Deyo RA, Diehr P, Patrick DL. Reproducibility and responsiveness of health status measures. Statistics and strategies for evaluation. Controlled Clin Trials 1991;12(Suppl 4):142-158.

29. Nunnally JC. Editor. Psychometric theory. 2nd ed. New York: Mc GrawHill, 1978.

30. Andresen EM. Criteria for assessing the tools of disability outcomes research. Arch Phys Med Rehabil 2000;81(Suppl 2):S15-S20.
31. Portney LG, Watkins MP. Foundation of clinical research: Applications to Practice. Norwalk, CT: Appleton Lange.1993.

32. Uchikawa K, Liu M, Hanayama K, Tsuji T, Fujiwara T, Chino N. Functional Status and Muscle Strength in People with Duchenne Muscular Dystrophy Living in the Community. J Rehabil Med 2004;36:124-129.

33. Mc Donald CM, Abresch RT, Carter GT. Profiles of Neuromuscular Diseases. Duchenne Muscular Dystrophy. Am J Phys Med Rehabil 1995;74:740-792.

34. Verheyden G, Nieuwboer A, Winckel A, De Weerdt W. Clinical Tools to Measure Trunk Performance After Stroke: A Systematic Review of the Literature. Clin Rehabil 2007;21:387-394. 